most salient legacies of a Marxist approach evident in these sections is the focus on conflicts between different resource use modes. Refreshingly, Gadgil and Guha avoid dwelling at length on the usual, overused stories of conflict, such as that of the Chipko movement, and instead move quickly to lesser-known incidents which serve just as admirably to illustrate their points. They also avoid some of the black-and-white cliches so common in writings about colonial resource exploitation in the third world. For example, although British forestry policies are pinpointed as one major cause of forest depletion and conflicts, the authors also clearly demonstrate, often with direct quotes from colonial administrators' writings, that some of the administrators openly opposed the prevailing policies. They also decline to exonerate all Indian rulers, some of whose directives are shown to be more deleterious to forest dwellers and farmers than British policies. The result is an analysis that for the most part is refreshingly frank and balanced in its assessments.

Having detailed many problems in Indian forest use, the authors' closing remark that "it is too early to say" (p. 245) whether a new mode of resource use will prevail is initially disappointing. However, from the very first chapter Gadgil and Guha maintain that "given the complexity of ecological communities, precise prescriptions for the prudent use of living resources are difficult" (p. 23). Recognizing this complexity, they thus avoid the simplistic suggestions, such as that resource management should devolve entirely to local communities, that often conclude similar books. Finally, given the subtitle "ecological history," perhaps one should not expect solutions for the future to be explicitly laid out. Rather, it is ultimately contingent upon the reader to delve deeply into the historical analysis for any lessons it might hold.

Reference cited: Roy P. Ellen, Environment, Subsistence, and System: the Ecology of Small-Scale Social Formations. Cambridge: Cambridge University Press, 1982. pp. 89-93.

\title{
Orientalism and the Postcolonial Predicament: Perspectives on South Asia. By Carol A. Breckenridge and Peter van der Veer, editors. 1993. Philadelphia: University of Pennsylvania Press. viii, 355 pp.
}

\author{
Reviewed by James F. Fisher, Professor of Anthropology, Carleton College, \\ Northfield, Minnesota.
}

In 1978 Edward Said of Columbia University published a book, Orientalism, which created a sizable stir among humanists and social scientists concerned with the nonWestern world. Said argued unequivocally, and trenchantly, that western knowledge about the Orient was not just the product of disinterested scholarship, but "a systematic discourse by which Europe was able to manage--and even produce--the Orient politically, sociologically, militarily, ideologically, scientifically, and imaginatively." Orientalism, as he called this phenomenon, helped the West to control and exploit the Orient. Said, a Palestinian by origin, used the Mideast as his prime example of Orientalism, but he meant his sweeping claim to apply to all of the "Orient." 
In Orientalism and the Postcolonial Predicament, Breckenridge and van der Veer have brought forth a collection of articles devoted to discussing the Said thesis in the context of "the modern countries of South Asia, which include India, Pakistan, Bangladesh, and Sir Lanka." Whether Nepal and other South Asian countries are excluded because they are not modern, or because they were not colonies, is not clear.

What is clear is that the Said position seems most compelling when applied to the colonial world in colonial times. The "postcolonial predicament," or at least one part of it, turns on this point: in what forms does the Western creation of reality in which others have to live continue in today's world of independent states? The editors of the volume argue that "decolonization does not entail immediate escape from colonial discourse [and that] this predicament defines both the ex-colonizer and the ex-colonized." Nobody, it seems, can escape from history.

Most of the chapters were originally delivered at the University of Pennsylvania as papers at the 1988-1989 Annual South Asia Seminar, devoted to "Orientalism and Beyond." The ten contributors to the volume approach the predicament in different, albeit overlapping ways. The first section is called "The Postcolonial Predicament and Contemporary History." Van der Veer argues not that Orientalism caused communalism, but that both are rooted in the common discourse of modernity. Lele claims not only that Orientalism distorts the Orient, but that its offshoot, the modernization paradigm, prevents us from seeing our own pathologies in the West. In a similar vein, Pollock shows how Orientalism, with its delineation of South Asia into Aryan and non-Aryan components, contributed to the development of anti-Semitism in Germany. Spivak focuses on English as an Indianized phenomenon in which it operates as a vehicle for controlling colonials. Along similar lines, Dharwadker demonstrates that what we might otherwise take as the common sense notion of "Indian literature" owes its existence to idiosyncratic European ideas of what constitutes literature.

In the second section ("The Genealogy of the Postcolonial") the remaining five authors look at Orientalism more historically. Lelyveld draws a fascinating portrait of how a "native" language--Hindustani-- was actually a creation of "the colonial imagination that set out to create a common language" in north India, where languages changed every eight miles. Rocher traces much of the familiar acrimonious Hindu/Muslim division to 18th century British attempts to reduce complex and fluid indigenous matters to legal texts of those two traditions. Ludden attempts to show that what came to be regarded as neutral "facts" (such as the existence of autonomous village communities, Hinduism, and caste) were creations of systematizing and record-keeping for official colonial purposes. Alternative and competitive views of what constitutes bare-bones "facts" were silenced. Dirks discusses the case of Colin MacKenzie, an East India Company official whose collaboration with a corps of native assistants resulted in an enormous collection of documents and artifacts, which were eventually co-opted by later hegemonic colonial interests. Finally, Appadurai writes of the ways in which European concern with quantification (as in such seemingly innocent ways as measuring land by cadastral survey, and enumerating people by community in a census) helped create an assumption that aggregates of people were separable from any kind of territorial context.

All these writers share in the Saidian and/or Foucaultian tradition of concern with the insidious relations between knowledge and power, and their attendant buzzwords of "discourse" and its peculiar adjectival form, "discursive" (Lelyveld's paper is refreshingly clear of this language). It is odd that in an otherwise admirably coherent and carefully edited volume the citation conventions of the different papers are not uniform; some are in 
the form of notes while others are bibliographies. The restatements of the Orientalist project are at times repetitive, and inevitably so, but the subtly different takes on Said, and the thoughtful exceptions taken to his position, add to the clear problematic focus of the volume.

These papers add substantially to our understanding of how the western gaze has transformed South Asia. They also struggle to show how we can go beyond it, but one is left with the feeling that all this epistemological agonizing leaves us in a solipsistic state which denies genuine, discoverable cultural differences "out there," quite apart from the way Orientalism has helped create them. The effect of Orientalism on our understanding is a little like the effect of childhood experiences on adult personality. We all have them, and we are unquestionably better off for recognizing and coming to grips with them, but we can't let them stop us from getting on with the problems of living. Certainly Orientalist history, like any history, is constructed out of our own parochial concerns and interests, but that admission need not paralyse us from investigating and making truth claims about the past of empirical cultural Others.

We have always known the ethnocentric pitfalls of judging other people's corn by our own bushels. This volume sounds the additional warning that counting dry volume measures may blind us from understanding what the most important and relevant things about grain are. It shows us not just how colonialism constructed the Orient, but how we continue to be trapped in our "postcolonial predicament" by the political and social categories we have inherited from the colonial era. History becomes in more ways than one the Joycean nightmare from which we are trying to awake.

\title{
EcoPopulism: Toxic Waste and the Movement for Environmental Justice. By Andrew Szasz. Minneapolis: University of Minnesota Press, 1994.
}

\author{
Reviewed by Daniel Brook.
}

Along with many other social movements, environmentalism grew stronger in its 1960s incarnation. In 1970, the year of the first Earth Day (on 22 April), it looked like payday for the environmental movement as a flurry of legislation passed through the Congress and was signed by President Nixon: the Resource Recovery Act, Environmental Protection Agency, Occupational Safety and Health Administration, Clean Air Act, Mining Enforcement and Safety Administration, Consumer Product Safety Commission, and National Highway Traffic Safety Administration. Whereas the first wave of environmentalism in the United States focused on the conservation of beautiful locales and culminated in the construction of a National Park System (beginning with Yellowstone National Park on 1 March 1872), the second wave of the 1960s emphasized general health and safety in the age of modernity, as opposed to aesthetics, and resulted in the Acts of 1970 and the institutionalization of Earth Day. The third and current wave of environmentalism began on 2 August 1978, when the mass media ran stories on the tragedy of Love Canal. It is to the genesis and development of this current wave that EcoPopulism is dedicated. 